\title{
Lysosomal membrane stability and respiration rate in zebra mussel (Dreissena polymorpha Pallas, 1771) as biomarkers for ex situ heavy metal exposure
}

\author{
V. YANCHEVA ${ }^{1}$ \\ I. MOLLOV ${ }^{1}$ \\ I. VELCHEVA ${ }^{1}$ \\ S. STOYANOVA ${ }^{2, *}$ \\ K. TODOROVA ${ }^{3}$ \\ E. GEORGIEVA ${ }^{2}$ \\ Department of Ecology and Environmental \\ Conservation, Faculty of Biology, Plovdiv University, \\ Plovdiv, 4000, Bulgaria \\ 2Department of Developmental Biology, Faculty of \\ Biology, Plovdiv University, Plovdiv, 4000, Bulgaria \\ ${ }^{3}$ Lyuben Karavelov Branch, Kardzhali, Bulgaria, \\ Plovdiv University, Plovdiv, 4000, Bulgaria

\section{Correspondence:} \\ Stela Stoyanova \\ E-mail: stela.st@abv.bg
}

Keywords: Dreissena polymorpha, Heavy metals; Lysosomes; Neutral red retention; Respiration rate

Abbreviations: $\mathrm{AA}$ - annual average concentration $M A C$ - maximum allowable concentration, NRRA - neutral red retention assay, NRRT - neutral red retention time.
Received November 08, 2016

Revised October 11, 2017.

Accepted December 27, 2017.

\begin{abstract}
Background and purpose: In the current study we aimed to investigate the lysosomal membrane stability in haemocytes of the invasive mollusk zebra mussel (Dreissena polymorpha Pallas, 1771) by applying the neutral red retention assay (NRRA), as well as changes in the respiration rate and survival under acute heavy metal exposure.
\end{abstract}

Materials and methods: The mussels were treated with different decreasing concentrations of nickel (Ni) and lead (Pb) in laboratory conditions for a total acute period of 72 hours. These metals are considered as priority substances in surface waters according to Directive 2013/39/EU of the European parliament and of the Council amending Directives 2000/60/EC and 2008/105/EC as regards priority substances in the field of water policy. The metal concentrations were prepared as 75,50 and $25 \%$ of the maximum allowable concentrations (100\% MAC) set by law.

Results and conclusions: In sum, after 24 and $72 \mathrm{~b}$ we found that the lysosomes in the mussels exposed to all $\mathrm{Ni}$ and $\mathrm{Pb}$ concentrations, including the ones below the MAC (75 and $50 \%$ from $M A C$ ) retained the dye shorter than the accepted minimum of 90 min. In addition, the respiration rate increased in a dose-dependent manner. Overall, we can conclude that the acute metal exposure lead to destabilization of the lysosomal membrane stability and changes in the respiration rate of zebra mussel, therefore altered physiological functions. We consider that such experiments could be successfully applied in risk assessment and monitoring programs on metal-contaminated aquatic systems, and the obtained results could be used in the field of water policy, respectively.

\section{INTRODUCTION}

Tn recent years, heavy metal pollution in the environment and food Ihas been considered as a global issue $(1,2)$. Large quantities of heavy metals have been released into aquatic systems, both fresh and marine worldwide due to a global rapid population growth and intensive domestic activities, as well as expanding industrial and agricultural production $(3,4)$. Thus, heavy metals have severely deteriorated the aquatic ecosystems because of their toxicity, abundance, persistence, and subsequent bioaccumulation and biomagnification (5).

To monitor the health of aquatic systems, sentinel organisms such as mussels (bivalves) have been proposed to be suitable "biomonitors" of pollution as they accumulate heavy metals in their tissues and shells 
$(6,7)$. Their filtering habits, low metabolism and ability to bioaccumulate pollutants make them an excellent choice to assess their bioavailability and effects (8-10). Mussels are also sessile, sedentary, have a reasonable size, they are worldwide distributed and often found in large amounts (11-13).

Marine mussels such as Mytilus sp., have been most often addressed as sensitive indicators for monitoring toxic substances in water (14-17). However, other bivalve species belonging to different taxa, such as Dreissena polymorpha have also been successfully used in ecotoxicological studies and monitoring programs (18-27).

The immune defence of mussels is comprised of cellmediated and humoral mechanisms, in which the haemocytes or blood cells play a key role (28). They are also involved in the detoxification process through the accumulation of metallic and organic xenobiotics in their well-developed endolysosomal system (29). Lysosomes are highly conserved multi-functional cellular organelles present in almost all cells of eukaryotic organisms, from yeast to humans. Their function in the cellular economy includes the degradation of redundant or damaged organelles (e.g., mitochondria and endoplasmic reticulum) and longer lived proteins as part of the autophagic cellular turnover (30). Lysosomes are also involved in normal physiological responses such as the digestion of materials ingested by endocytosis and phagocytosis (i.e., intracellular digestion) $(30,31)$. Moreover, the lysosomal system, which is remarkably well-developed in mussel haemocytes is well-known as a target site for toxic metals and organic chemicals, due to its ability to accumulate them (32-36). As a consequence, the cell health deteriorates after lysosomal damage induced by different contaminants. The damage is mainly due to rapid weakening of the lysosomal membranes, which may release hydrolitic enzymes into the cytoplasm with subsequent enhanced protein catabolism up to the autophagic conditions indicating a stress syndrome (34).

The stability of the lysosomal membranes is evaluated using the lysosomal membrane stability test (LMS) of the digestive gland $(37,38)$, as well as in vitro using the neutral red retention assay (NRR) of the haemocyte lysosomes. NRR measures the lysosomal content efflux into the cytosol, which in stressed mussels, reflects a physiological process after membrane damage and comparatively measures the capacity of cellular processes to adapt to stress conditions (39).

In environmental risk assessment, the use of a battery of biomarkers is strongly recommended (40-42) because a comprehensive and integrated view of the biological responses of aquatic organisms, even where the levels of contaminants are not particularly high can be studied (43). In this sense, the destabilization of lysosomal membranes is an established indicator for toxically induced adverse effects in fish and shellfish $(44,45)$. Lysosome enlargement, as well as lysosome number increase, are further morphological alterations of the lysosomal system basically due to the increase in protein turnover, which in molluscs have been considered as reliable signals of cellular stress and damage, resulting from enhanced autophagy additionally as a response to external stimuli such as contaminants (46-49). The rate of respiration reflects the metabolic activities of animals and the responses due to changes in the surrounding environment could also be an indicator of adjustment capacity of the organism. Furthermore, bivalve molluscs reflect immediate responses to toxic substances present in the surrounding water by changes in their physiological responses (48).

The main goal of the current research was to study how nickel $(\mathrm{Ni})$ and lead $(\mathrm{Pb})$, which are considered as priority substances according to Directive 2013/39/EU of the European parliament and the Council could possibly impact the physiology of relatively resilient and invasive zebra mussel (Dreissena polymorpha Pallas, 1771) under ex situ laboratory conditions. Thus, we aimed to study two biomarker responses: 1) Lysosomal membrane stability by applying the neutral red retention assay and 2) Respiration rate index. These particular methods were chosen as they are simple, easy to perform and quite inexpensive.

\section{MATERIALS AND METHODS}

\section{Experimental animals}

About 230 specimens of the same size-group (mean length $2.5 \mathrm{~cm} \pm 0.5$ ) were hand collected in the spring of 2015 from "Ovcharitsa" Reservoir, located in southeastern Bulgaria. The mussels were placed in 101 containers filled with the reservoir water and transported quickly to the laboratory on the same day. After transportation the mussels were moved in $100 \mathrm{l}$ glass aquaria with chlorine-free tap water (by evaporation) to acclimatize for a week. The water was kept oxygen saturated. During the entire duration of the experiment the mussels were maintained under a natural light/dark cycle (12:12). They were not fed.

\section{Experimental exposure}

After acclimatization the mussels were divided into eight groups ( $\mathrm{n}=25$ in each experimental $50 \mathrm{l}$ tank). The mussels were treated with different soluble in water concentrations of $\mathrm{Ni}\left(\mathrm{NO}_{3}\right)_{2}$ and and $\mathrm{Pb}\left(\mathrm{NO}_{3}\right)_{2}$ for 72 hours. The metal concentrations were prepared as 75,50 and $25 \%$ of MAC (100\%) set by law. According to the Bulgarian legislation based on Directive 2013/39/EU (50), MAC of Ni in inland surface waters is $20 \mathrm{\mu g} \mathrm{l}^{-1}$ $(100 \%)$ and that of $\mathrm{Pb}-14 \mu \mathrm{g} \mathrm{l^{-1 }}(100 \%)$, respectively. Therefore, $750 \mu \mathrm{g}$ (75\% from MAC), $500 \mu \mathrm{g}(50 \%), 250$ $\mu \mathrm{g}(25 \%) \mathrm{Ni}$, as well as $270 \mu \mathrm{g}(75 \%), 180 \mu \mathrm{g}(50 \%)$ and $70 \mu \mathrm{g}(25 \%) \mathrm{Pb}$ were applied for $50 \mathrm{l}$ tanks in the current experiment. No mussel mortality was recorded during the exposure period.

The physico-chemical characteristics of the aquarium water such as: $\mathrm{pH}$, temperature, oxygen level and conductivity were measured once at the start of the experiment, 
as well as on the $24^{\text {th }}$ and $72^{\text {nd }}$ hour according to a standard procedure with a combined portable field-meter (WTW, Germany).

\section{Neutral red retention assay}

The analytical procedure was adapted from Lowe and Pipe (39) and Lowe et al. (44). It is based on the use of a cationic probe neutral red, which is taken up into the cells by membrane diffusion where it becomes ion trapped within the lysosomal compartment (51-54). Over the time, the dye tends to leak out of the lysosomes into the cytosol, which is then stained by the dye (55). The exposure to toxic substances damages the lysosomal membrane and hence, increases its permeability. The end point parameter is the time at which a dye loss to the cytosol is evident in $50 \%$ of the granular haemocytes. The rounding up of the cells and enlargement of the lysosomes is also associated with dye loss.

Haemolymph (about $0.5 \mathrm{ml}$ ) was withdrawn from the posterior adductor muscle of 10 mussels from each experimental tank using a $2.5 \mathrm{ml}$ syringe containing an equal volume of calcium-magnesium free physiological solution (CMFS: $4.77 \mathrm{~g} \mathrm{l}^{-1} \mathrm{HEPES}, 25.48 \mathrm{~g} \mathrm{l}^{-1} \mathrm{NaCl}, 0.75 \mathrm{~g}$ $\mathrm{l}^{-1} \mathrm{KCl}, 1000 \mathrm{ml} \mathrm{Di} \mathrm{H}_{2} \mathrm{O}$ ) as described by Molnar and Fong (56) in order to obtain a 50/50 of the cell/physiological solution. The suspension of $40 \mu \mathrm{l}$ was spread onto the center of microscope slides, transferred to a lightproof humidity chamber and allowed to attach. The slides were removed individually from the chamber and the excess suspension was carefully tipped off on a paper towel. Then, $40 \mu$ of the working solution $(10 \mu$ into $5 \mathrm{ml}$ physiological saline from a stock solution of $4 \mathrm{mg}$ Neutral Red (C.I. 50040 Sigma) in $1 \mathrm{ml}$ of dimethyl sulfoxide) was added to the cell monolayer. On the top of each slide a $22 \times 22 \mathrm{~mm}$ cover slip was placed. After $15 \mathrm{~min}$. incubation the slides were examined systematically using a light microscope (Nikon, Eclipse E200). The time period between the neutral red (NR) probe application and the appearance of the first evidence of dye loss from the lysosomes to the cytosol in at least $50 \%$ of the examined cells belonging to the granular haemocytes represents the neutral red retention time (NRRT) for the mussels. Following a further $15 \mathrm{~min}$., each preparation was observed at $30 \mathrm{~min}$. intervals until a total time of $180 \mathrm{~min}$.

\section{Respiration rate}

The respiration rate was measured at the start of the experiment when the toxicants were applied $(0 \mathrm{~h})$, at the $24^{\text {th }}$ hour and at the end of the experiment ( $72^{\text {nd }}$ hour). At the given time 20 mussels were transferred in 1.21 glass tanks filled with water from the test aquariums. The oxygen levels were measured, using a combined portable fieldmeter (WTW, Germany). The tanks were then covered with plastic foil in order to eliminate any oxygen transfer. They were left for one hour and thereafter, the oxygen level was measured again. The respiration rate was calculated by determining the difference in the dissolved oxygen levels before and after, following Tsekov (57): $I=Q_{2} / G$, where I-respiration rate index; $G$ - weight of the mussels, in grams, $Q_{2}$ - oxygen consumed by the mussels between the two measurements (the difference between the oxygen levels before and after $1 \mathrm{~h}, \mathrm{Q}_{2}=\mathrm{Q}-\mathrm{Q}_{1}$ hour). $\mathrm{Q}$ was calculated by the following formula: $\mathrm{Q}=\mathrm{V} \times \mathrm{q}$, where: $\mathrm{Q}-$ total oxygen level; $\mathrm{V}$ - water volume, in litres; $\mathrm{q}$ - level of dissolved oxygen in 1 litre of water $\left(\mathrm{mg} \mathrm{l}^{-1}\right)$.

\section{Statistical analysis}

For the statistical processing of the data the software package "Statistica 7.0" (StatSoft Inc. 2004) was used. Student's t-test and one-way analysis of variance (ANO$\mathrm{VA}$ ) were applied to see if there was a significant difference between the NRRT of the control and mussels examined at the $24^{\text {th }}$ and $72^{\text {nd }}$ hour. In addition, Spearman's correlation analysis was used, when the data is not normally distributed in order to examine the changes of the respiration rate, along with the metal concentrations. Significance level was set to 0.01 and 0.05 .

\section{RESULTS AND DISCUSSION}

\section{Water properties}

The physico-chemical properties of the water showed relatively constant values in all nine experimental tanks (Table 1). These for the control groups were as follows: $\mathrm{pH}-8.1$; conductivity $-435 \mu \mathrm{cm}^{-1}$, oxygen level -6.5 $\mathrm{mg} \mathrm{l^{-1 }}$ and temperature $-21.5^{\circ} \mathrm{C}$, respectively. In general, the values between the $24^{\text {th }}$ and $72^{\text {nd }} \mathrm{h}$ were similar

Table 1. Physico-chemical properties in the experimental water tanks, average results at the start of the experiment ( 0 h), 24 ${ }^{\text {th }}$ and $72^{\text {nd }} \mathrm{h}$ (average $\pm S D$ ).

\begin{tabular}{|ccccc|}
\hline Metal concentration, $\mu \mathrm{g} \mathrm{l}{ }^{-1}$ & $\mathrm{pH}$ & Conductivity, $\mu \mathrm{cm}^{-1}$ & Temperature, ${ }^{\circ} \mathrm{C}$ & ${\text { Oxygen level, } \mathrm{mg} \mathrm{l}^{-1}}$ \\
\hline Ni 1000 & $7.98 \pm 0.5$ & $492 \pm 1.5$ & $21.75 \pm 1$ & $6.3 \pm 0.5$ \\
Ni 750 & $8.1 \pm 0.5$ & $490 \pm 1$ & $20.75 \pm 1.5$ & $6.3 \pm 0.3$ \\
Ni 500 & $8.15 \pm 0.5$ & $489.5 \pm 0.5$ & $22.75 \pm 1.3$ & $6.5 \pm 0.5$ \\
Ni 250 & $8.02 \pm 0.3$ & $489 \pm 0.5$ & $22 \pm 0.5$ & $6.6 \pm 0.1$ \\
Pb 360 & $8.12 \pm 0.5$ & $486.5 \pm 0.5$ & $23.5 \pm 0.5$ & $6.2 \pm 0.5$ \\
Pb 270 & $8.13 \pm 0.3$ & $488 \pm 0.3$ & $22.75 \pm 0.5$ & $6.4 \pm 0.5$ \\
Pb 180 & $8.2 \pm 0.5$ & $483.5 \pm 0.3$ & $21.75 \pm 0.5$ & $6.5 \pm 0.3$ \\
Pb 70 & $8.195 \pm 0.3$ & $480.5 \pm 1.5$ & $21.75 \pm 0.3$ & $6.5 \pm 0.3$ \\
\hline
\end{tabular}


for the studied period. Therefore, we consider that the changes, which we observed in the lysosomal membrane stability and respiration rate were not due to changes in the abiotic factors of the water.

\section{Neutral red retention time}

The results on lysosomal membrane stability of the control and exposed mussels to $\mathrm{Ni}$ and $\mathrm{Pb}$ after the $24^{\text {th }}$ and $72^{\text {nd }}$ hour are presented in Fig. 1 and 2. The average NRRT of the dye in the mussels from the control groups $\left(0,24^{\text {th }}\right.$ and $72^{\text {nd }}$ hour $)$ was 106 min., with a maximum average time of $110 \mathrm{~min}$. for the mussels examined at the beginning of the experiment. There was no significant difference between the NRRT for the controls $(p>0.05)$. Overall, the lysosomes of control mussels could be considered as healthy and non-stressed; with no destabilized lysosomes since destabilization of the lysosomal membrane stability was not observed before the $90^{\text {th }} \mathrm{min}$.

On the other hand, significant reductions in the indices of the lysosomal membrane stability were registered in the treated with heavy metals mussels after 24 and 72 hours. We found that the lysosomal membrane stability changed with the concentration of both metals. The lowest NRRT was measured in the mussels exposed to the highest heavy metals concentrations, which represent MAC in inland surface waters according to the national and EU legislation.

For example, the mussels subjected to the action of $1000 \mu \mathrm{g} \mathrm{Ni}$ for $24 \mathrm{~h}$ had an average NRRT ofonly 48 min. The mussels treated with 750 and $500 \mu \mathrm{g}$ Ni retained the dye little longer -78 and $90 \mathrm{~min}$., while those treated with $250 \mu \mathrm{g}$ Ni showed lysosomal destabilization on the $102^{\text {nd }} \mathrm{min}$. The statistical analysis of the data dem-

Neutral Red Retention Assay, 24 h

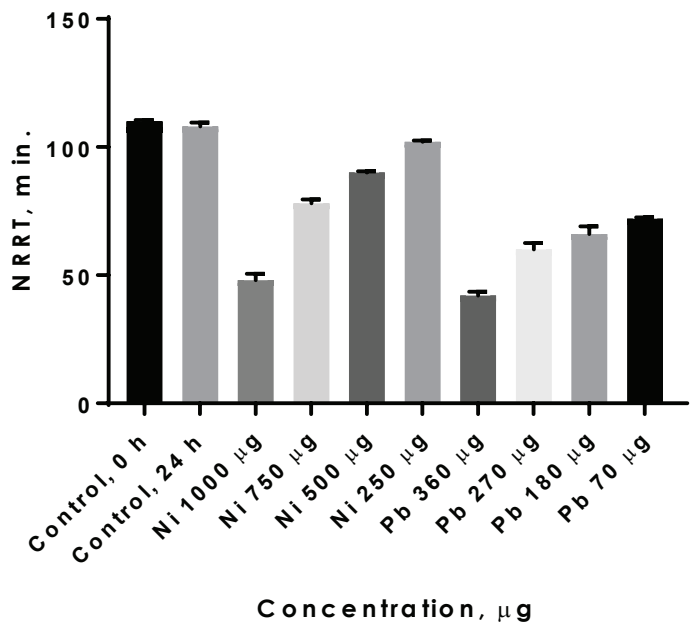

Figure 1. Average neutral red retention time in zebra mussels exposed to $\mathrm{Ni}$ and $\mathrm{Pb}$ for $24 \mathrm{~h}$ (whiskers representing standard deviation). onstrated a significant difference $(p=0.01)$ between the NRR time of the dye in the lysosomes of mussels exposed to $1000 \mu \mathrm{g} \mathrm{Ni}$ and the control. Statistically significant differences were not found among the mussels exposed to the other Ni concentrations and the control $(p>0.05)$. Similarly, the mussels treated with $\mathrm{Pb}$ for 24 hours showed an analogous trend in retaining of the dye - a shorter time at the higher heavy metal concentrations and a longer time at the lower concentrations. The mussels treated with $\mathrm{Pb}$ concentration of $360 \mu \mathrm{g}$ had an average NRRT only $42 \mathrm{~min}$. At concentration of 270,180 and $70 \mu \mathrm{g}$ the lysosomal destabilization was recorded respectively at the $60^{\text {th }}, 66^{\text {th }}$ and $72^{\text {nd }}$ min. The statistical analysis demonstrated significant differences between the NRRT of the dye in the mussel lysosomes from the control group and all $\mathrm{Pb}$ concentrations $(p<0.05)$. After the $72^{\text {nd }} \mathrm{h}$ the mussels exposed to Ni concentration of $1000 \mu \mathrm{g}$ showed leaking of the dye from the lysosomes in the cytosol just after $30 \mathrm{~min}$. The mussels treated with 750, 500 and $250 \mu \mathrm{g}$ held the dye 42, 54 and $72 \mathrm{~min}$., respectively. The statistical data processing proved significant differences $(p<$ 0.05 ) between the NRRT of the mussels exposed to all $\mathrm{Ni}$ concentrations and the control. The picture for the mussels after $72 \mathrm{~h}$ exposure to $\mathrm{Pb}$ was similar to that of $\mathrm{Ni}$, i.e. at the higher metal concentrations destabilization of the lysosomal membranes was established earlier. The mussel lysosomes exposed to $\mathrm{Pb}$ concentration of $360 \mu \mathrm{g}$ held the dye only $30 \mathrm{~min}$. and those exposed to 270,180 and $70 \mu \mathrm{g}-36,54$ and $66 \mathrm{~min}$., respectively, which also confirmed the disturbances, occurring in the the cell organelles. The applied t-test proved significant statistical differences between the NRRT of the dye in the mussel lysosomes from the control group and all four $\mathrm{Pb}$ concentrations $(p<0.05)$. We found statistically significant dif-

Neutral Red Retention Assay, 72 h

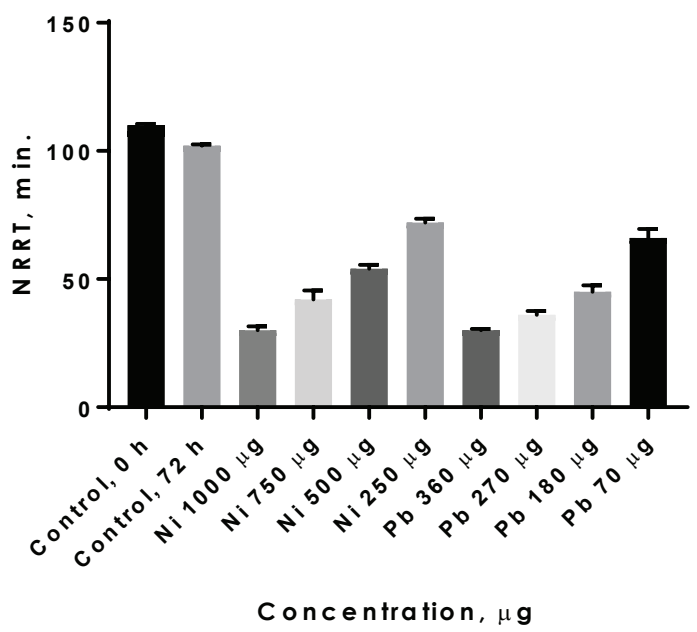

Figure 2. Average neutral red retention time in zebra mussels exposed to $\mathrm{Ni}$ and $\mathrm{Pb}$ for $72 \mathrm{~h}$ (whiskers representing standard deviation). 
ferences between the groups exposed to 750 and $250 \mu \mathrm{g}$ $\mathrm{Ni}(p=0.033 ; p=0.034)$ comparing the NRRT of the dye in the lysosomes of the mussels treated with $\mathrm{Ni}$ on the $24^{\text {th }}$ and $72^{\text {nd }}$ hour). None were found for the mussels exposed to $\mathrm{Pb}$ on the $24^{\text {th }}$ and $72^{\text {nd }} \mathrm{h}(p>0.05)$.

Overall, in the international scientific literature more data is available on the effects of various organic pollutants (PAHs, PCBs, pharmaceutical products and oil derivatives) on the lysosomal membrane stability of different invertebrate species such as mussels, snails, etc. (27, 58$63)$ compared with heavy metals $(26,55,64)$. On the basis of the collected literature regarding the effects of heavy metals on the lysosomal membrane stability of mussels (and other mollusc species) we found that our results are similar with those of other authors and confirm that the lysosomal stability weakens with the increasing toxicant concentrations, and vice versa - the retention time of the dye is longer for the lower concentrations.

For example, Molnar and Fong (56) applied the neutral red retention assay to investigate the effects of $\mathrm{Cd}$ and $\mathrm{Cu}$ on two species of freshwater molluscs (Elliptio complanata and Helisoma trivolvis). The authors found that the mussels and snails exposed to heavy metals showed a significant increase in the percentage of destabilized lysosomes compared to the control, as well as after 7 and 14 days after exposure for all the concentrations, which were applied. Scott-Fordsmand et al. (65) also applied the same method to study the effects of different $\mathrm{Ni}$ concentrations on Eisenia veneta and established a similar trend. In their research Svendsen and Weeks (66) studied Cu toxicity on Viviparu scontectus at concentrations of 31 to $100 \mu \mathrm{g} \mathrm{l}^{-1}$. The authors found that all tested concentrations resulted in a significantly shorter NRR time in comparison with the control. Shepard and Bradley (67) demonstrated that the lysosomal destabilization in Mytilus edulis was dosedependent; as such occurred only after $24 \mathrm{~h}$ exposure of 20-80 $\mu \mathrm{g} \mathrm{l}^{-1} \mathrm{Cu}$. Nicholson (68) found that the NRRT decreased with the increasing $\mathrm{Cu}$ concentrations in the mussel Perna viridis. Such a conclusion was also made by Matozzo et al. (69) for Tapes philippinarum after exposure to $\mathrm{Cu}$ and $\mathrm{Cd}$ at concentrations of $10-110 \mu \mathrm{g} \mathrm{l}^{-1}$. These authors also demonstrated that $\mathrm{Cd}$ had more pronounced toxicity on the lysosomes in this species compared to $\mathrm{Cu}$.

In the present study we also tested different concentrations of two heavy metals $-\mathrm{Ni}$ and $\mathrm{Pb}$, and found that $\mathrm{Pb}$ has more negative effects on zebra mussel in terms of lysosomal membrane stability. Although, no significant differences were proven in the NRRT in the lysosomes exposed to all $\mathrm{Ni}$ and $\mathrm{Pb}$ concentrations on the $24^{\text {th }}$ and $72^{\text {nd }} \mathrm{h}$, our results demonstrated that the NRRT time was shorter for the mussels, exposed to $\mathrm{Pb}$. Therefore, we could consider that $\mathrm{Pb}$ has more severe toxicity compared to $\mathrm{Ni}$ in terms of faster lysosmal destabilization. Probably the most significant result, which we obtained from this experiment, was that interference occurred at cellular level in the mussels treated with $\mathrm{Ni}$ and $\mathrm{Pb}$ concentrations lower than the MAC. Similarly, Yancheva et al. (70) studied the effect of different concentrations of $\mathrm{Cd}$ and $\mathrm{PAH}$; equaled to MAC according to Directive 2013/39/EU, $50 \%$ above and $50 \%$ below MAC on zebra mussels, and found similar results - destabilization in the lysosomal membranes occurred even in the groups treated with lower than the permissible concentrations. In this sense, in some western countries the legislation related to water quality uses not only annual average concentrations (AA) or MAC, but also no observed effect and low observed effect concentrations (NOEC and LOEC) - for aquatic organisms such as fish, mollusks, etc.

Although, our data is obtained from a single laboratory study, we consider that these results could be taken into account and serve as a basis for comparison with other results in similar future studies, as well as monitoring programs on freshwater ecosystems under anthropogenic pressure.

\section{Respiration rate}

The results from the respiration rate measurements are presented in Table 2. After $24 \mathrm{~h}$ of exposure we recorded a very strong, positive (which was statistically significant only for $\mathrm{Pb}$ ) correlation between the concentration of both metals and the index of respiration rate $(\mathrm{Pb}-s=$ $0.97, p=0.006 ; \mathrm{Ni}-s=0.85, p=0.07$ ). At the end of the experiment this correlation remained almost unchanged $(\mathrm{Pb}-s=0.96, p=0.009 ; \mathrm{Ni}-s=0.82, p=0.08)$, which we could link to the toxic effect of $\mathrm{Ni}$ and $\mathrm{Pb}$ on this studied parameter.

A similar pattern was observed by Nikolov et al. (71) in zebra mussel treated with $\mathrm{Zn}$ for $96 \mathrm{~h}$. The mussels increased their respiration rate with the heavy metal concentration. A study by Kraak et al. (72) suggests that the effects of $\mathrm{Zn}$ and $\mathrm{Pb}$ on the filtration rate of zebra mussel also increased when the exposure time was increased. It is known that without time for acclimation the mussels typically reduce their clearance rate (volume of water passing through gills per unit time), thus potentially lowering their intake of oxygen (73). However, most bivalve molluscs reflect immediate responses to toxic substances present in the surrounding water by changes in the physiological responses (52). In most cases the respiration rate increases with the increase of the pollutant concentration and level of toxicity (51). Our results are in agreement with Yancheva et al. (27) who studied the negative effects of different concentrations of chlorpyrifos on zebra mussels and found that the respiration rate was increased compared to the control group. The same authors also investigated the effects of $\mathrm{Cd}$ on two freshwater mollusks (26) and concluded that the respiration rate was higher in the Chinese pond mussel and zebra mussel after 24 and $72 \mathrm{~h}$ compared to the control. Probably the reason for this is that the organism, triggered by the stress, caused by the 
Table 2. Index of respiration rate of zebra mussel exposed to different $\mathrm{Ni}$ and $\mathrm{Pb}$ concentrations at the start of the experiment $\left(\mathrm{O}\right.$ b), $24^{\text {th }}$ and $72^{\text {nd }}$ hour.

\begin{tabular}{|c|c|c|c|c|c|c|c|c|}
\hline \multirow{3}{*}{$\begin{array}{c}\text { Test } \\
\text { variant }\end{array}$} & \multirow{3}{*}{$\begin{array}{c}\text { Water } \\
\text { volume, L }\end{array}$} & \multirow{3}{*}{$\begin{array}{l}\text { Weight, } \\
\text { g (G) }\end{array}$} & \multicolumn{5}{|c|}{ Total oxygen level $\left(\mathrm{mg} \mathrm{L}^{-1}\right)$} & \multirow{3}{*}{$\begin{array}{l}\text { Index of } \\
\text { respiration } \\
\text { rate }(\mathrm{I})\end{array}$} \\
\hline & & & \multicolumn{2}{|c|}{ Beginning } & \multicolumn{2}{|c|}{ End } & \multirow{2}{*}{$\frac{\text { Total }}{\left(\mathrm{Q}_{2}\right)}$} & \\
\hline & & & $\mathrm{q}$ & Q & $\mathrm{q}_{\mathrm{lh}}$ & $\mathrm{Q}_{\mathrm{lh}}$ & & \\
\hline \multicolumn{9}{|c|}{ Beginning (0 hour) } \\
\hline Control & 1.2 & 13.76 & 8.8 & 10.56 & 7.4 & 8.88 & 1.68 & 0.12 \\
\hline $\mathrm{Pb}-70$ & 1.2 & 12.88 & 9.7 & 11.64 & 7.8 & 9.36 & 2.28 & 0.17 \\
\hline $\mathrm{Pb}-180$ & 1.2 & 13.47 & 8.7 & 10.44 & 7.4 & 8.88 & 1.56 & 0.12 \\
\hline $\mathrm{Pb}-270$ & 1.2 & 13.14 & 9.1 & 10.92 & 8.0 & 9.60 & 1.32 & 0.1 \\
\hline $\mathrm{Pb}-360$ & 1.2 & 13.62 & 9.4 & 11.28 & 8.1 & 9.72 & 1.56 & 0.12 \\
\hline $\mathrm{Ni}-250$ & 1.2 & 14.68 & 9.1 & 10.92 & 7.0 & 8.40 & 2.52 & 0.17 \\
\hline $\mathrm{Ni}-500$ & 1.2 & 13.46 & 9.0 & 10.80 & 7.2 & 8.64 & 2.16 & 0.16 \\
\hline $\mathrm{Ni}-750$ & 1.2 & 13.83 & 9.2 & 11.04 & 7.1 & 8.52 & 2.52 & 0.18 \\
\hline $\mathrm{Ni}-1000$ & 1.2 & 13.42 & 9.7 & 11.64 & 7.7 & 9.24 & 2.40 & 0.18 \\
\hline \multicolumn{9}{|c|}{$24^{\text {th }}$ hour } \\
\hline Control & 1.2 & 13.47 & 9.1 & 10.92 & 8.7 & 10.44 & 0.48 & 0.036 \\
\hline $\mathrm{Pb}-70$ & 1.2 & 13.25 & 8.3 & 9.96 & 7.7 & 9.24 & 0.72 & 0.054 \\
\hline $\mathrm{Pb}-180$ & 1.2 & 12.16 & 8.8 & 10.56 & 7.9 & 9.48 & 1.08 & 0.089 \\
\hline $\mathrm{Pb}-270$ & 1.2 & 11.68 & 9 & 10.8 & 8.1 & 9.72 & 1.08 & 0.093 \\
\hline $\mathrm{Pb}-360$ & 1.2 & 11.15 & 8.7 & 10.44 & 7.7 & 9.24 & 1.20 & 0.108 \\
\hline $\mathrm{Ni}-250$ & 1.2 & 13.02 & 8.9 & 10.68 & 7.8 & 9.36 & 1.f & 0.101 \\
\hline $\mathrm{Ni}-500$ & 1.2 & 12.28 & 8.9 & 10.68 & 7.8 & 9.36 & 1.32 & 0.107 \\
\hline $\mathrm{Ni}-750$ & 1.2 & 11.43 & 8.4 & 10.08 & 7.3 & 8.76 & 1.32 & 0.115 \\
\hline $\mathrm{Ni}-1000$ & 1.2 & 11.82 & 8.5 & 10.2 & 7.3 & 8.76 & 1.44 & 0.122 \\
\hline \multicolumn{9}{|c|}{$72^{\text {nd }}$ hour } \\
\hline Control & 1.2 & 12.52 & 7.7 & 9.24 & 7.0 & 8.40 & 0.84 & 0.07 \\
\hline $\mathrm{Pb}-70$ & 1.2 & 12.07 & 8.6 & 10.32 & 7.7 & 9.24 & 1.08 & 0.09 \\
\hline $\mathrm{Pb}-180$ & 1.2 & 12.13 & 8.5 & 10.20 & 7.5 & 9.00 & 1.20 & 0.09 \\
\hline $\mathrm{Pb}-270$ & 1.2 & 11.27 & 8.2 & 9.84 & 7.2 & 8.64 & 1.20 & 0.12 \\
\hline $\mathrm{Pb}-360$ & 1.2 & 12.39 & 8.5 & 10.20 & 7.3 & 8.76 & 1.44 & 0.12 \\
\hline $\mathrm{Ni}-250$ & 1.2 & 13.16 & 8.4 & 10.08 & 7.9 & 9.48 & 0.60 & 0.05 \\
\hline $\mathrm{Ni}-500$ & 1.2 & 13.16 & 8.9 & 10.68 & 8.0 & 9.60 & 1.08 & 0.08 \\
\hline $\mathrm{Ni}-750$ & 1.2 & 11.88 & 8.4 & 10.08 & 7.5 & 9.00 & 1.08 & 0.09 \\
\hline $\mathrm{Ni}-1000$ & 1.2 & 11.99 & 8.3 & 9.96 & 7.3 & 8.76 & 1.2 & 0.1 \\
\hline
\end{tabular}

toxic exposure, tries to deliver more oxygen to all tissues and organs. This was also the case with zebra mussel in the present experiment; the mussels reacted by increasing their respiration rate with the increasing metal concentrations after the $24^{\text {th }} \mathrm{h}$, and this pattern remained unchanged until the $72^{\text {nd }} \mathrm{h}$ of exposure. As stated by Naimo (74) analyses of freshwater mussels can indicate metal bioavailability and these organisms may be useful in more sensitive, sublethal toxicity tests. However, most studies on the effects of heavy metals on freshwater mussels have concerned bioaccumulation. Experimental research should incorporate complex measurements, which examine the links between sublethal toxicity and bioaccumula- tion in freshwater mussels. Thus, more immediate information on exposure concentrations and physiological activity of freshwater mussels will be needed.

\section{CONCLUSION}

In summary, in Bulgaria, heavy metal pollution remains a problem, particularly in regions with intensive industry. Thus, in 1995 five hot spots were indicated in the country for this type of pollution, which are linked to the activity of metallurgical plants, smelters and refiners. However, not many studies deal with the negative effects of metals on freshwater mussels. Based on the data from 
the present experiment we can conclude that $\mathrm{Ni}$ and $\mathrm{Pb}$ had severe effects on the physiology of zebra mussel, which led to a destabilized cellular compartment and altered respiration functions. We confirmed that neutral red retention assay is a feasible, non-specific biomarker and proved that the respiration rate measurement could also be applied as biomarker for heavy metal contamination in similar studies. Moreover, the negative impact of both heavy metals was observed at concentrations lower than MAC. We suggest that further research in this particular area need to be repeated in order to study in details the heavy metal effects on zebra mussels, which are considered relatively resilient to changes in the surrounding media. The results could be carefully considered in the field of water legislation and conservation, respectively.

\section{Acknowledgments}

This study was supported by the NPD - Plovdiv University "Paisii Hilendarski" under Grant No NI15-BF-003, Integrated biological approaches for monitoring priority substances in water.

\section{REFERENCES}

1. CUI BS, ZHANG QJ, ZHANG KJ, LIU XH, ZHANG HG 2011 Analyzing trophic transfer of heavy metals for food webs in the newly-formed wetlands of the Yellow River Delta, China. Environ Pollut 159(5): 1297-1306.

https://doi.org/10.1016/j.envpol.2011.01.024

2. YUAN GL, LIU C, CHEN L, YANG Z 2011 Inputting history of heavy metals into the inland lake recorded in sediment profiles: Poyang Lake in China. J Hazard Mater 185: 336-345. https://doi.org/10.1016/j.jhazmat.2010.09.039

3. SREBOTNJAK T, CARR G, DE SHERBININ A, RICKWOOD C 2012 A global water quality index and hot-deck imputation of missing data. Ecol Indic 17: 108-119.

https://doi.org/10.1016/j.ecolind.2011.04.023

4. ISLAM MS, HAN S, MASUNAGA S 2014 Assessment of trace metal contamination in water and sediment of some rivers in Bangladesh. J Water Environ Technol 12: 109-121. https://doi.org/10.2965/jwet.2014.109

5. ALIZ, MALIK RN, QADIR A 2013 Heavy metals distribution and risk assessment in soils affected by tannery effluents. Chem Ecol 29: 676-692. https://doi.org/10.1080/02757540.2013.810728

6. RAINBOW PS 1993 The significance of trace metal concentrations in marine invertebrates. In: Dallinger R, Rainbow PS (eds) Ecotoxicology of metals in invertebrates. Lewis Publishers, Boca Raton, $\mathrm{p}$ 3-23.

7. BESADA V, ANDRADE JM, SCHULTZE F, GONZALEZ J 2011 Monitoring of metals in wild mussels (Mytilus galloprovincialis) from the Spanish North-Atlantic coast. Cont Shelf Res 31(5): 457-465. https://doi.org/10.1016/j.csr.2010.04.011

8. BAYNE BL 1989 Measuring the biological effects of pollution: the mussel watch approach. Water Sci Technol 21: 1089-1100.

9. FOSSATO VU, CAMPESAN G, RABOLEDDA LC, STOCCO G 1989 Trends in chlorinated hydrocarbons and heavy metals in organisms from the Gulf of Venice. Arch Oceanograph Limnol 21: 179-190.

10. WIDDOWS J, DONKIN P 1992 Mussels and environmental contaminants: bioaccumulation and physiological aspects. In: Gosling E (ed) Developments in aquaculture and fisheries science. The mussel Mytilus: ecology, physiology, genetics and culture. Elsevier, Amsterdam, p 383-398.

11. GOLDBERG ED 1980 The international mussel watch. National Academy of Sciences, Washington, DC.

12. FARRINGTON JW, GOLDBERG ED, RISEBROUGH RW, MARTIN JH, BOWEN VT 1983 U.S. mussel watch 1976-1978: an overview of the trace-metal, DDE, PCB, hydrocarbon and artificial radionuclide data. Environ Sci Technol 17: 490-496. https://doi.org/10.1021/es00114a010

13. GOLDBERG ED 1986 The mussel watch concept. Environ Monit Assess 7: 91-103. https://doi.org/10.1007/BF00398031

14. ZATTA P, GOBBO S, ROCCO P, PERAZZOLO M, FAVARATO M 1992 Evaluation of heavy metal pollution in the Venetian lagoon by using Mytilus galloprovincialis as a biological indicator. Sci Total Environ 119: 29-41. https://doi.org/10.1016/0048-9697(92)90253-O

15. HAGGER JA, JONES MB, LOWE D, LEONARD DRP, OWEN R, GALLOWAY TS 2008 Application of biomarkers for improving risk assessments of chemicals under the Water Framework Directive: a case study. Mar Pollut Bull 56: 1111-1118. https://doi.org/10.1016/j.marpolbul.2008.03.040

16. WEPENER V, DEGGER N 2012 Status of pollution research in South Africa (1960-present). Mar Pollut Bull 64: 1508-1512. https://doi.org/10.1016/j.marpolbul.2012.05.037

17. ROUANE-HACENE O, BOUTIBA Z, BELHAOUARI B, GUIBBOLINI-SABATIER M E, FRANCOUR P, RISSO-DE FAVERNEY C 2015 Seasonal assessment of biological indices, bioaccumulation and bioavailability of heavy metals in mussels Mytilus galloprovincialis from Algerian west coast, applied to environmental monitoring. Oceanologia 57(4): 362-374.

18. CAMUSSO M, BALESTRINI R, MURIANO F, MARIANI M 1994 Use of freshwater mussel Dreissena polymorpha to assess trace metal pollution in the lower River Po (Italy). Chemosphere 29(4): 729-745. https://doi.org/10.1016/0045-6535(94)90042-6

19. DE LAFONTAINE Y, GAGNÉ F, BLAISE C, COSTAN G, GAGNON P, CHAN HM 2000 Biomarkers in zebra mussels (Dreissena polymorpha) for the assessment and monitoring of water quality of the St Lawrence River (Canada). Aquat Toxicol 50: 51-71. https://doi.org/10.1016/S0166-445X(99)00094-6

20. JOHNS C, TIMMERMAN BE 1998 Total cadmium, copper, and zinc in two Dreissenid mussels, Dreissena polymorpha and Dreissena bugensis, at the Outflow of Lake Ontario. J Great Lakes Res 24(1): 55-64. https://doi.org/10.1016/S0380-1330(98)70799-3

21. GUERLET E, LEDY K, MEYER A, GIAMBERINI L 2007 Towards a validation of a cellular biomarker suite in native and transplanted zebra mussels: a 2-year integrative field study of seasonal and pollution induced variations. Aquat Toxicol 81: 377-388. https://doi.org/10.1016/j.aquatox.2006.12.016

22. BINELLI A, COGNI D, PAROLINI M, PROVINI A 2010. Multi-biomarker approach to investigate the state of contamination of the R. Lambro/R. Po confluence (Italy) by zebra mussel (Dreissena polymorpha). Chemosphere 79(5): 518-528. https://doi.org/10.1016/j.chemosphere.2010.02.033

23. FARIA M, HUERTAS D, SOTO DX, GRIMALT JO, CATALAN J, RIVA MC, BARATA C 2010 Contaminant accumulation and multi-biomarker responses in field collected zebra mussels (Dreissena polymorpha) and crayfish (Procambarus clarkii), to evaluate toxicological effects of industrial hazardous dumps in the Ebro river (NE Spain). Chemosphere 78(3): 232-240.

https://doi.org/10.1016/j.chemosphere.2009.11.003

24. LEPOM P, IRMER U, WELLMITZ J 2012 Mercury levels and trends (1993-2009) in bream (Abramisbrama L.) and zebra mussels (Dreissena polymorpha) from German surface waters. Chemosphere 86(2): 202-211. https://doi.org/10.1016/j.chemosphere.2011.10.021 
25. BINELLI A, DELLA TORRE C, MAGNI S, PAROLINI M 2015 Does zebra mussel (Dreissena polymorpha) represent the freshwater counterpart of Mytilus in ecotoxicological studies? A critical review. Environ Pollut 196: 386-403. https://doi.org/10.1016/j.envpol.2014.10.023

26. YANCHEVA V, MOLLOV I, VELCHEVA I, GEORGIEVA E, STOYANOVA S 2016 Effects of cadmium (Cd) on the lysosomal membrane stability and respiratory rate of two freshwater mollusks under ex situ exposure: preliminary data. South-West J Hortic Biol Environ 7(1): 27-34.

27. YANCHEVA V, MOLLOV I, GEORGIEVA E, STOYANOVA S, TSVETANOVA V, VELCHEVA I 2017 Ex situ effects of chlorpyrifos on the lysosomal membrane stability and respiration rate in Zebra mussel (Dreissena polymorpha Pallas, 1771). Acta Zool Bulg S8: 85-90

28. CHENG TC 1981 Bivalves. In: Ratcliffe NA, Rowley AF (eds) Invertebrate blood cells. Academic Press, London, p 233-300.

29. CAJARAVILLE MP, PAL SG 1995 Morphofunctional study of the hemocytes of the bivalve mollusc Mytilus galloprovincialis with emphasis on the endolysosomal compartment. Cell Struct Funct 20: 355-336. https://doi.org/10.1247/csf.20.355

30. KLIONSKY DJ, EMR SD 2000 Autophagy as a regulated pathway of cellular degradation. Science 290: 1717-1721. https://doi.org/10.1126/science.290.5497.1717

31. CUERVO AM 2004 Autophagy: in sickness and in health. Trends Cell Biol 14: 70-77. https://doi.org/10.1016/j.tcb.2003.12.002

32. DE DUVE C, DE BARSY T, POOLE B, TROUET P, TULKENS P, VAN HOOF F 1974 Lysosomotropic agents. Biochem Pharmacol 23: 2495-2531. https://doi.org/10.1016/0006-2952(74)90174-9

33. MOORE MN 1985 Cellular responses to pollutants. Mar Pollut Bull 16: 134-139. https://doi.org/10.1016/0025-326X(85)90003-7

34. VIARENGO A, MOORE MN, PERTICA M, MANCINELLI G, ZANICCHI G, PIPE RK 1985 Detoxification of copper in the cells of the digestive gland of mussel: The role of lysosomes and thioneins. Sci Total Environ 44: 135-145. https://doi.org/10.1016/0048-9697(85)90117-2

35. VIARENGO A, MOORE MN, MANCINELLI G, MAZZUCOTELLI A, PIPE RK, FARRAR SV 1987 Metallothioneins and lysosomes in metal toxicity and accumulation in marine mussels: the effect of cadmium in the presence and absence of phenanthrene. Mar Biol 94: 251-257. https://doi.org/10.1007/BF00392937

36. MOORE MN 1990 Lysosomal cytochemistry in marine environmental monitoring. Histochem 22: 187-191. https://doi.org/10.1007/BF02386003

37. DOMOUHTSIDOU GP, DIMITRIADIS VK 2001 Lysosomal and lipid alterations in the digestive gland of mussels, Mytilus galloprovincialis (L.) as biomarkers of environmental stress. Environ Pollut 115: 123-137. https://doi.org/10.1016/S0269-7491(00)00233-5

38. PETROVIC S, OZRETIC B, KRAJNOVIC-OZRETIC M, BOBINAC D 2001 Lysosomal membrane stability and metallothioneins in digestive gland of mussels (Mytilus galloprovincialis Lam.) as biomarkers in a field study. Mar Pollut Bull 42(12): 1373-1378. https://doi.org/10.1016/S0025-326X(01)00167-9

39. LOWE DM, PIPE RK 1994 Contaminant induced lysosomal membrane damage in marine mussel digestive cells: an in vitro study. Aquat Toxicol 30: 357-365. https://doi.org/10.1016/0166-445X(94)00045-X

40. MONSERRAT JM, MARTİNEZ PE, GERACITANO LA, AMADO LL, MARTINS C, LOPES G, PINHO L, CHAVES IS, FERREIRA-CRAVO M, VENTURA-LIMA J, BIANCHINI A 2007 Pollution biomarkers in estuarine animals: critical review and new perspectives. Comp Biochem Physiol C Toxicol Pharmacol 146: 221-234. https://doi.org/10.1016/j.cbpc.2006.08.012
41. IACONO F, CAPPELLO T, CORSARO C, BRANCA C, MAISANO M, GIOFFRÈ G, DE DOMENICO E, MAUCERI A, FASULO S 2010 Environmental metabolomics and multibiomarker approaches on biomonitoring of aquatic habitats. Comp Biochem Physiol A Mol Integr Physiol 157: 50.

https://doi.org/10.1016/j.cbpa.2010.06.143

42. FASULO S, BRUNELLI E, MAISANO M, SPERONE E, MAUCERI A, BERNABÒ, I, Cappello T, D'AGATA A, TRIPEPI S 2012 Toxicity of Foroozan crude oil to ornate wrasse (Thalassoma pavo): Ultrastructure and cellular biomarkers by using integrated approaches. Ital J Zool 79: 182-199.

43. CRAVO A, LOPES B, SERAFIM A, COMPANY R, BARREIRA L, GOMES T, BEBIANNO M J 2009 A multibiomarker approach in Mytilus galloprovincialis to assess environmental quality. J Environ Monit 11: 1673-1686. https://doi.org/10.1039/b909846a

44. LOWE DM, FOSSATO VU, DEPLEDGE MH 1995 Contaminant-induced lysosomal membrane damage in blood cells of mussels Mytilus galloprovincialis from the Venice Lagoon: an in vitro study. Mar Ecol Prog Ser 129: 189-196.

https://doi.org/10.3354/meps129189

45. FERNLEY PW, MOORE MN, LOWE DM, DONKIN P, EVANS S 2000 Impact of the Sea Empress oil spill on lysosomal stability in mussel blood cells. Mar Environ Res 50: 451-455. https://doi.org/10.1016/S0141-1136(00)00118-5

46. LOWE DM, MOORE MN, CLARKE KR 1981 Effects of oil on digestive cells in mussels: quantitative alterations in cellular and lysosomal structure. Aquat Toxicol 1: 213-226. https://doi.org/10.1016/0166-445X(81)90016-3

47. MOORE MN, VIARENGO A 1987 Lysosomal membrane fragility and catabolism of cytosolic proteins - evidence for a direct relationship. Experientia 43: 320-323. https://doi.org/10.1007/BF01945568

48. HWANG H-M, WADE TL, SERICANO JL 2002 Relationship between lysosomal membrane destabilization and chemical body burden in eastern oysters (Crassostre virginica) from Galveston Bay, Texas, USA. Environ Toxicol Chem 21: 1268-1271. https://doi.org/10.1002/etc.5620210622

49. ALLEN JI, MOORE MN 2004 Environmental prognostics: is the current use of biomarkers appropriate for environmental risk evaluation. Mar Environ Res 58: 227-232. https://doi.org/10.1016/j.marenvres.2004.03.119

50. DIRECTIVE 2013/39/EU of European Parliament and of the Council amending Directives 2000/60/EC and 2008/105/EC as regards priority substances in the field of water policy. Official Journal of the European Union.

51. KUMAR S, PANDEY RK, DAS S, DAS VK 2012 Dimehoate alters respiratory rate and gill histopathology in freshwater mussel Lamellidens marginatus (Lamarck). J Appl Biosci 38(2): 154-158.

52. BASHA SM, SWAMI KS, PUSPANJALI A 1988 Ciliary and cardiac activity of freshwater mussel Lamellidens marginalis (Lamark) as an index of evaluating oranophosphate toxicity. J Environ Biol 9(3): 313-318.

53. NEMES Z, DIETZ R, LÜTH JB, GOMBA S, HACKENTHAL E, GROSS F 1979 The pharmacological relevance of vital staining with neutral red. Experientia 35: 1475-1476. https://doi.org/10.1007/BF01962793

54. RASHID F, HOROBIN RW, WILLIAMS MA 1991 Predicting the behaviour and selectivity of fluorescent probes for lysosomes and related structures by means of structure-activity models. Histochem J 23: 450-459. https://doi.org/10.1007/BF01041375

55. HARREUS D, KOÈHLER HR, WEEKS JM 1997 Combined noninvasive cell isolation and neutral-red retention assay for measuring the effect of copper on the lumbricid Aporrectodea rosea (Savigny). Bull Environ Contam Toxicol 59: 44-49. https://doi.org/10.1007/s001289900441 
56. MOLNAR N, FONG PP 2012 Toxic effects of copper, cadmium, and methoxychlor shown by neutral red retention assay in two species of freshwater molluscs. The Open J Environ Pollut Toxicol 3: 65-71. https://doi.org/10.2174/1876397901203010065

57. TSEKOV A 1989 Studies on transferrin polymorphism in carp and its resistance to oxygen deficiency. Genet Select 22(6): 517-522 (In Bulgarian).

58. MINIER C, ABARNOU A, JAOUEN-MADOULET A, LE GUELLEC A-M, TUTUNDJIAN R, BOCQUENÉ, LEBOULENGE F 2006 A pollution-monitoring pilot study involving contaminant $\mathrm{G}$ and biomarker measurements in the Seine Estuary, France, using zebra mussels (Dreissena polymorpha). Environ Toxicol Chem 25(1): 112-119.

59. BINELLI A, COGNI D, PAROLINI M, RIVA C, PROVINI A 2009 Cytotoxic and genotoxic effects of in vitro exposure to triclosan and trimethoprim on zebra mussel (Dreissena polymorpha) hemocytes. Comp Biochem Physiol C 150: 50-56. https://doi.org/10.1016/j.cbpc.2009.02.005

60. SHAW JP, DONDERO F, MOORE MN, NEGRI A, DAGNINO A, READMAN JW, LOWE DR, FRICKERS PE, BEESLEY A, THAIN JE, VIARENGO A 2011 Integration of biochemical, histochemical and toxicogenomic indices for the assessment of health status of mussels from the Tamar Estuary, U.K. Mar Environ Res 72: 13-24. https://doi.org/10.1016/j.marenvres.2011.05.003

61. PATETSINI E, DIMITRIADIS VK, KALOYIANNI M 2013 Biomarkers in marine mussels, Mytilus galloprovincialis, exposed to environmentally relevant levels of the pesticides, chlorpyrifos and penoxsulam. Aquat Toxicol 126: 338-345. https://doi.org/10.1016/j.aquatox.2012.09.009

62. TURJA R, SOIRINSUO A, BUDZINSKI H, DEVIER MH, LEHTONEN KK 2013 Biomarker responses and accumulation of hazardous substances in mussels (Mytilus trossulus) transplanted along a pollution gradient close to an oil terminal in the Gulf of Finland (Baltic Sea). Comp Biochem Physiol C 157: 80-92. https://doi.org/10.1016/j.cbpc.2012.09.006

63. TURJA R, HÖHER N, SNOEIJS P, BARŠIENĖ J, BUTRIMAVIČIENĖ L, KUZNETSOVA T, KHOLODKEVICH SV, DEVIER M-H, BUDZINSKI H, LEHTONEN KK 2014 A multibiomarker approach to the assessment of pollution impacts in two Baltic Sea coastal areas in Sweden using caged mussels (Mytilus trossulus). Sci Total Environ 473-474: 398-409. https://doi.org/10.1016/j.scitotenv.2013.12.038

64. YANCHEVA V, MOLLOV I, VELCHEVA I, GEORGIEVA E, STOYANOVA S 2016 Heavy metal effects on the lysosomal membrane stability and respiratory rate in Chinese Pond Mussel (Sina- nodonta woodiana) under ex situ exposure: preliminary data. Biharean Biologist 10(1): 55-57.

65. SCOTT-FORDSMAND JJ, WEEK JM, HOPKIN SP 1998 Toxicity of nickel to the earthworm and the applicability of the neutral red retention assay. Ecotoxicol 7: 291-295. https://doi.org/10.1023/A:1008824531114

66. SVENDSEN C, WEEKS JM 1995 The use of a lysosome assay for the rapid assessment of cellular stress from copper to the freshwater snail Viviparus contectus (Millet). Mar Pollut Bull 31: 139-142. https://doi.org/10.1016/0025-326X(94)00227-Z

67. SHEPARD JL, BRADLEY BP 2000 Protein expression signatures and lysosomal stability in Mytilus edulis exposed to graded copper concentrations. Mar Environ Res 50: 457-463. https://doi.org/10.1016/S0141-1136(00)00119-7

68. NICHOLSON S 2001 Ecocytological and toxicological responses to copper in Perna viridis (L.) (Bivalvia: Mytilidae) haemocyte lysosomal membranes. Chemosphere 45: 399-407. https://doi.org/10.1016/S0045-6535(01)00039-X

69. MATOZZO V, BALLARIN L, PAMPANIN DM, MARIN MG 2001 Effects of copper and cadmium exposure on functional responses of hemocytes in the clam, Tapes philippinarum. Arch Environ Contamin Toxicol 41: 163-170. https://doi.org/10.1007/s002440010234

70. YANCHEVA V, GEORGIEVA E, STOYANOVA S, TSVETANOVA V, TODOROVA K, MOLLOV I, VELCHEVA I 2018 Short and long-term toxicity of cadmium $(\mathrm{Cd})$ and polyaromatic hydrocarbons (PAHs) on zebra mussel (Dreissena polymorpha Pallas, 1771). Acta Zool Bulg (In Press)

71. NIKOLOV B, SALAPATIYSKA S, GEORGIEV D 2009 A study of the survival and oxygen deficiency at the zebra mussel (Dreissena polymorpha) treated with zinc (Zn). Ecol Balk 1: 5-8 (In Bulgarian).

72. KRAAK MHS, WINK YA, STUIJFZAND SC, BUCKERT-DE JONG MC, DE GROOT CJ, ADMIRAAL W 1994 Chronic ecotoxicity of $\mathrm{Zn}$ and $\mathrm{Pb}$ to the zebra mussel Dreissena polymorpha. Aquat Toxicol 30: 77-89. https://doi.org/10.1016/0166-445X(94)90007-8

73. ALDRIDGE DW, PAYNE BS, MILLER AC 1987 The effects of intermittent exposure to suspended solids and turbulence on three species of freshwater mussels. Environ Pollut 45: 17-28. https://doi.org/10.1016/0269-7491(87)90013-3

74. NAIMO TJ 1995 A review of the effects of heavy metals on freshwater mussels. Ecotoxicol 4: 341-362. https://doi.org/10.1007/BF00118870 